\title{
ANTECEDENTS OF ACADEMIC PERFORMANCE OF UNIVERSITY STUDENTS: \\ Academic Engagement and Psychological Capital
}

Isabel M. Martínez. Universitat Jaume I. Avenida de Vicent Sos Baynat, s/n 12071 Castelló de la Plana. Spain. Telephone: +34 964729585; e-mail: Isabel.martinez@uji.es

*Carolyn M. Youssef-Morgan. Bellevue University. College of Business, 1000 Galvin Road South, Bellevue, NE 68005. USA. Telephone: 1402557 7565; e-mail: cyoussefmorgan@ bellevue.edu

Maria J. Chambel, Universidade de Lisboa, Faculdade de Psicologia. Alameda da Universidade, 1649-013 Lisboa, Portugal. Telephone: +351 217943655; e-mail: mjchambel@fp.ul.pt Alexandra Marques-Pinto. Universidade de Lisboa, Faculdade de Psicologia. Alameda da Universidade, 1649-013 Lisboa, Portugal. Telephone: +351 217943655; e-mail: ampinto@psicologia.ulisboa.pt

Author note: This research was supported by a grant the Consellería de Educación Generalitat Valenciana - Programa Prometeo (PROMETEO/2013/025). Antecedents of Academic Performance of University Students: Academic Engagement and Psychological Capital 


\begin{abstract}
Predicting academic performance is of key importance to the success, wellbeing and prosperity of students, their families, the economy, and the society at large. This study investigates the relationship between academic engagement, psychological capital (PsyCap) and academic performance. Data were collected in two different universities, one in Spain and another in Portugal. Students completed two self-report questionnaires regarding academic engagement and Psychological Capital. Academic performance was assessed through Grade Point Average, provided by the universities at the end of the exam period. The samples consisted of 389 and 243 undergraduate students, respectively. Results showed a positive relationship between academic engagement and PsyCap, on the one hand, and academic performance on the other, in both samples. Results also supported PsyCap as a full mediator in the relationship between academic engagement and academic performance. Exploration of alternative models yielded superior fit for the proposed model. Accordingly, academically engaged students were likely to experience higher levels of PsyCap, which in turn positively impacted their academic performance. The results point to the importance of considering psychological predictors, rather than the prevalent reliance on traditional predictors of academic performance.
\end{abstract}

KEYWORDS: academic engagement, psychological capital, academic performance, college students. 
Antecedents of Academic Performance of University Students: Academic Engagement and Psychological Capital

Predicting academic performance has been an important priority for many reasons. Students and parents are eager to determine the best allocation of their financial and time investments (Cabrera \& La Nasa, 2000). School and university administrators also invest extraordinary amounts of time and resources to ensure preparedness, effective placement and favorable outcomes for their students (Adelman, 2006). Policymakers and taxpayers are keen to keep student loans, grants, and other forms of public college funding resources under control and effectively allocated to ensure maximum societal impact and minimize default rates (Hauser \& Johnston, 2016).

However, college spending continues to escalate, while success rates continue to decline, and loan default rates continue to rise. For example, in the United States, the amount of outstanding student loans in 2015 exceeded \$1.2 trillion (Federal Reserve, 2015). One in ten Americans and almost half of American households headed by an individual under 35 had at least some outstanding student loans (Fry, 2012). The default rate on these loans currently ranges between 10 and 20 percent depending on the type of educational institution (U.S. Department of Education, 2013). Graduation rates after six years of enrollment are in the 60 percent range, which contributes to the rising student loan default rates (National Center for Education Statistics, 2016).

Similar trends exist in other parts of the world. Although college education is free or heavily subsidized in many European, Asian, and Middle Eastern countries, taxpayers in these countries typically absorb the costs, and thus expect a rigorous process for selecting students 
with the highest likelihood of success. However, graduation rates are not impressive. For example, Germany now offers free college education, yet the average college graduation rate is 28 percent. Graduation rates are comparable in some other European countries: Italy 28 percent, Sweden 26 percent; slightly better in some: Portugal 36 percent, Netherlands 41 percent, Belgium 42 percent, United Kingdom, 45 percent, Finland 46 percent, Denmark 52 percent; and worse in others: Luxembourg 9 percent, Spain 18 percent, and Hungary 22 percent (Organization for Economic Cooperation and Development, 2015). These rates leave much to be desired in terms of justifying the exorbitant amounts of resources allocated to higher education and ensuring these resources are invested optimally. Thus, predicting academic performance is of key importance to the wellbeing and prosperity of students, their families, the economy, and the society at large.

Traditional predictors of academic performance often used as college admission requirements and selection tools include standardized aptitude tests (e.g., SAT, ACT), general and domain-specific Grade Point Average (GPA) in high school or early college courses, essays, interviews, and extracurricular activities (Schmidt \& MacWilliams, 2011; Truell, \& Woosley, 2008; Young \& Korbin, 2001). However, as evident from the statistics reported earlier, these predictors are insufficient. Other important psychosocial and structural factors may influence students' abilities and motivation to succeed (Arce, Crespo, \& Míguez-Álvarez, 2015; Richardson, Abraham, \& Bond, 2012). For example, college life includes stressful changes such as being separated from friends and family, moving to a new geographic location, establishing a new social network, responding to new teaching methods and evaluation systems, making important vocational choices, and preparing for the transition to the job market. For many students, these changes are successfully navigated, but for some students, these challenges can 
compromise their wellbeing and academic performance, even though these students may have met all of the traditional entrance requirements.

The purpose of this study is to begin to fill this gap. Specifically, we conceptualize and empirically examine two psychological states as predictors of academic performance, namely psychological capital (PsyCap) and academic engagement. Indeed, previous research supports psychological factors such as personality, motivation, perseverance, and self-efficacy as important predictors of academic performance (Enright \& Gitomer, 1989; Oswald et al., 2004; Salanova, Schaufeli, Martínez \& Bresó, 2010, Zajacova, Lynch, \& Espenshade, 2005). These studies highlight the need to take into account the role of students' psychological resources in the prediction of academic performance in higher education. Moreover, extensive cross-sectional, longitudinal, and experimental research supports positivity as an antecedent and a cause of numerous forms of success (Lyubomirsky, King, \& Diener, 2005). Both PsyCap and engagement are positive constructs and rooted in positive psychology (Seligman \& Csikszentmihalyi, 2000). Thus, investigating them in the context of academic performance is informed by existing theory and empirical evidence.

In addition to examining PsyCap and academic engagement as antecedents of academic performance, we also propose and test PsyCap as a mediator of the relationship between engagement and performance. There were only few studies about the relationship between PsyCap and academic performance (Luthans, Luthans, \& Jensen, 2012), as well as between PsyCap and academic engagement (Siu, Bakker, \& Jiang, 2013), between student academic engagement and academic performance (Bakker, Sanz Vergel, \& Kuntze, 2015; Jang, Kim, \& Reeve, 2012; Kuh, Cruce, Shoupe, \& Kinzie, 2008; Martin, 2009; Reeve \& Lee, 2014; Salanova et al., 2010), and between academic engagement and motivation (Reeve \& Lee, 2014). However, 
this is the first study to examine both psychological states concurrently in relation to academic performance, and to test a mediated model of these relationships. Figure 1 summarizes the proposed model.

[INSERT FIGURE 1 ABOUT HERE]

\section{OVERARCHING THEORETICAL FRAMEWORK}

We use three overarching theories to build the conceptual arguments for the hypothesized relationships in our proposed model: Conservation of Resources theory (COR; Hobfoll, 2002), Social Cognitive Theory (SCT; Bandura, 1986), and the Broaden-and-Build Model (BBM; Fredrickson, 2001). According to COR, the attainment and preservation of psychosocial resources are prime human motivations. People strive to accumulate and protect these resources. Resources can be valuable in and of themselves (e.g., self-esteem, health), or utilized as a way to obtain other desired ends (e.g., money, power, success, coping with challenges). COR also discusses 'gain spirals' (Hobfoll \& Shirom, 2000), in which positive reciprocal relationships occur between positively-oriented individual states. Resources travel together in "resource caravans" and can be utilized synergistically to facilitate building other resources (gain spirals). As discussed in subsequent sections, both PsyCap and engagement are positive psychological resources that can be used in conjunction to promote success. Furthermore, each of these constructs is conceptualized to be a multidimensional construct that includes several psychological states. Additionally, both resources are states that are malleable and open to development. Thus, COR is a particularly relevant theoretical framework in this study.

SCT is the second overarching theory that informs this study. SCT posits that behavior is the result of a dynamic interaction between social, cognitive, and personal factors. In addition to 
reflecting on past behavior and its consequences (i.e., behavioral reinforcement in psychology, organizational behavior modification in management), behavior is also shaped through cognitive symbolizing of tasks and thought patterns; forethought and planning to achieve desired goals; self-regulation to allocate resources and avoid distractions; and learning from similar role models facing comparable situations (Bandura, 1997, 2001). These mechanisms are self-directed, dynamic, and socially facilitated, rather than inherent, passive, or mechanistically determined. They promote agentic adaptation and self-regulation of motivation and action in pursuit of incresingly challenging but personally meaningful goals and aspirations, rather than complacency, 'slacking,' or giving up (Bandura, 2012). Student performance tends to hinge to a great extent on this 'stamina' or 'staying power,' as well as the ability to muster the motivation and resourcefulness to achieve goals. Thus, SCT is particularly relevant to this study's investigation of the psychological antecedents of academic performance.

The third overarching theory is Fredrickson's (2001) BBM. According to this model, positivity broadens people's thought-action repertoires so that they can expand their perspective and consider more diversified goals and a wider range of courses of action. In contrast, negativity narrows one's perspective to tried-and-true paths, excluding viable but perhaps more creative and venturesome approaches. Additionally, positivity facilitates the development (building) of additional physical, social, and psychological resources, which can be drawn upon in times of challenge or negativity. Depleted inventories of resources are then replenished in subsequent times of positivity. As mentioned earlier, college students deal with many life changes, as well as academic challenges. The broadening and building effects of positivity are necessary to overcome challenges and uncertainties while retaining focus and sustaining 
wellbeing, making BBM a relevant overarching theoretical framework for our model and population of interest, namely college students.

Finally, in order to advance the conceptualization of the relationship between student psychological states such as PsyCap and academic engagement, and their performance, we draw from the organizational literature. This approach is consistent with previous research. For example, Cotton, Dollard, and Jonge (2002) draw parallels between student work in an academic context and workplace dynamics. They utilize job design and work stress theories to explain wellbeing, satisfaction, and performance among Australian students. Indeed, like many employees, students work in structured environments, with well-defined tasks, academic demands, and varying levels of control. They are expected to meet deadlines, and their performance determines their progress and success. Similar conceptualizations of academics as analogous to a work setting have been supported in the literature (Chambel \& Curral, 2005; Winefield, 1993).

\section{Psychological Capital}

PsyCap is defined as "an individual's positive psychological state of development that is characterized by: (1) having confidence (self-efficacy) to take on and put in the necessary effort to succeed at challenging tasks; (2) making a positive attribution (optimism) about succeeding now and in the future; (3) persevering toward goals, and when necessary redirecting paths to goals (hope) in order to succeed; and (4) when beset by problems and adversity, sustaining and bouncing back and even beyond (resilience) to attain success" (Luthans, Youssef-Morgan, \& Avolio, 2015, p. 2). PsyCap is a derivative from positive organizational behavior (Luthans \& Youssef, 2007; Nelson \& Cooper, 2007; Wright, 2003) and positive organizational scholarship (Cameron \& Spreitzer, 2012), both of which are recognized movements in the organizational 
literature that apply positive psychology (Seligman \& Csikszentmihalyi, 2000) to the workplace. PsyCap can be simply viewed as "who you are" and "what you can become in terms of positive development" (Avolio \& Luthans, 2006). It is differentiated from and goes beyond human capital ("what you know"), social capital ("who you know"), and financial capital ("what you have") (Luthans, Luthans, \& Luthans, 2004; Luthans \& Youssef, 2004).

In line with COR (Hobfoll, 2002), PsyCap includes several distinct psychological resources that share commonalities but also vary meaningfully and contribute synergistically to positive outcomes. Shared commonalities include positivity, theory and evidence base, valid measurement, malleability and developmental potential, and link to performance and other desirable outcomes (Luthans, 2002a; 2002b). Four resources best fit these criteria: self-efficacy, hope, optimism, and resilience. The common theme shared by these four resources is a "positive appraisal of circumstances and probability for success based on motivated effort and perseverance” (Luthans, Avolio, Avey, \& Norman, 2007, p. 550). They also share conative, cognitive, affective, and social mechanisms (see Luthans \& Youssef-Morgan, 2016, for a comprehensive review). Indeed, COR suggests that self-efficacy, hope, optimism, and resilience collectively act as “a solid resource reservoir” (Hobfoll, 2002, p. 318). Research supports PsyCap as a higher-order, core construct that is a stronger predictor of attitudes and performance than any one of its four constituent psychological resources (Luthans, et al., 2007). A metaanalysis of 51 independent samples supports the relationship between PsyCap and a number of work attitudes (e.g., satisfaction, commitment, cynicism, turnover intentions, wellbeing, stress, anxiety), behaviors (e.g., organizational citizenship, deviance), and performance (Avey, Reichard, Luthans, \& Mhatre, 2011). 
More specifically, PsyCap self-efficacy is defined as “the individual's conviction or confidence about his or her abilities to mobilize the motivation, cognitive resources or courses of action needed to successfully execute a specific task within a given context" (Stajkovic \& Luthans, 1998b, p. 66). Self-efficacy is deeply rooted in SCT. Unlike personality traits and other stable predictors of success (e.g., IQ or aptitude), efficacy is malleable and can be developed through mastery, role modeling, social persuasion, and even physical or psychological health in general (Bandura, 1997). The relationship between self-efficacy and performance has been established in the workplace (Stajkovic \& Luthans, 1998a), as well as in many other life domains, including academic performance (Pintrich \& de Groot, 1990; Zajacova, et al., 2005; Zimmerman, Bandura, \& Martinez-Pons, 1992). According to COR, self-efficacy is a cognitive resource. Efficacious individuals are less likely to be affected by criticism, self-doubt, or setbacks (Bandura \& Locke, 2003). Thus, they are more likely to report greater positive functioning. Agentic and efficacious goal pursuit is of key importance for mustering the self-motivation, effort, and perseverance necessary to achieve one's goals and succeed at school and at work. Similarly, hope and optimism have been linked to academic performance (Curry, Snyder, Cook, Ruby, \& Rehm, 1997; Peterson \& Barrett, 1987; Prola \& Stern, 1984; Rand, Martin, \& Shea, 2011). Hope has been defined as "a positive motivational state based on an interactively derived sense of successful (a) agency (goal-directed energy) and (b) pathways (planning to meet goals)" (Snyder, Irving, \& Anderson, 1991, p. 287). Agency is the willpower pursue one's goals. Pathways are the 'waypower' or ability to generate alternative paths to achieve goals when original paths are blocked by obstacles (Snyder, 2000). While agency is a common theme in SCT and PsyCap, the pathways component is unique to hope. Hope has also been examined as an 
achievement emotion commonly experienced by students in the classroom and strongly related to mastery goals (Pekrun, Elliot, \& Maier, 2006).

Optimism is generalized positive future outlook that yields global positive expectancies (i.e., expecting good things to happen in general, Carver, Scheier, Miller, \& Fulford, 2009), as well as a positive explanatory style that attributes positive events to personal, permanent, and pervasive causes, and negative events to external, temporary, and situations-specific factors (Seligman, 1998). In PsyCap optimism, there is an emphasis on realism (Schneider, 2001) and flexibility (Peterson, 2000) in order to make accurate attributions and avoid delusion or evasion of responsibility.

Finally, resilience is defined as "the capacity to rebound or bounce back from adversity, conflict, failure or even positive events, progress and increased responsibility" (Luthans, 2002b, p.702). Consistent with COR and SCT, resilient individuals capitalize on their personal, social and psychological assets, synergistically deploying them toward effective adaptation patterns and processes in order to overcome adversities or risk factors (Hobfoll, Johnson, Ennis, \& Jackson, 2003; Masten, Cutuli, Herbers, \& Reed, 2009). Psychological resilience research originates primarily from the developmental psychology literature, particularly in the context of the many at-risk children and youth that 'beat the odds' and become successful and well-adjusted adults despite personal, family, or socioeconomic adversities (Masten, 2001). Parallels can be drawn between this population and the context of this study, namely college students conquering challenges and achieving academic performance. Also in line with the broadened thought-action repertoires and resource replenishment notions of BBM, resilience and PsyCap in general emphasize 'bouncing back and beyond,' which means learning from, growing, and thriving through challenges, rather than just recovery and return to 'normal.' 
Beyond the individual contributions of each of PsyCap's resources, PsyCap as a higherorder resource can contribute to academic performance in several ways. First, based on PsyCap's positive appraisals (Luthans, et al., 2007), college students who cognitively evaluate their situation and probability of success more positively and maintain a positive future outlook (optimism) are more likely to be motivated to invest the effort and perseverance necessary to succeed. Believing in themselves (self-efficacy), and determined to succeed (hope agency), they are more likely to deploy their conative mechanisms and exhibit higher agency, intentionality, and a sense of control (Youssef \& Luthans, 2013; Luthans \& Youssef-Morgan, 2013; Luthans, et al., 2015), all of which are necessary for academic performance. Second, high PsyCap students are likely to develop a wider range of pathways and strategies to overcome obstacles (hope) and to bounce back and learn from setbacks (resilience). Being more positive allows these students to have a broadened perspective and to draw from an expanded repertoire of physical resources (e.g., healthy diet, exercise, adequate sleep), social resources (e.g., seeking the help of professors and classmates), and psychological resources that can facilitate their performance.

In contrast, when faced with the everyday challenges of college life, low PsyCap students are more likely to exaggerate and internalize the impact of these situations (pessimistic explanatory style). They may resort to a narrow focus (e.g., stressing over a single assignment or one bad grade). This negativity can deplete their physical resources (e.g., pulling all-nighters, abusing alcohol or drugs, developing eating disorders), social resources (e.g., isolation, freeloading, cheating), and psychological resources, to the detriment of their adaptability and ability to cope effectively, rebound, and move on. Indeed, recent research supports the relevance and impact of academic PsyCap on students' performance and wellbeing, as well as the high value of PsyCap, even when compared to important factors such as instructor and family support 
(Luthans, et al., 2012; Luthans, Luthans, \& Avey, 2014; Nielsen, Newman, Smyth, Hirst, \& Heilemann, 2016). Thus, the following is hypothesized:

Hypothesis 1. Academic PsyCap is positively related to academic performance.

\section{Academic Engagement}

Engagement is a positive state characterized by vigor, dedication, and absorption. Vigor represents high energy levels and mental agility, manifested in terms of willingness to invest effort, and persistence when faced with difficulties. Dedication is being deeply involved in one's work, thus experiencing enthusiasm, inspiration, pride, challenge, and a sense of significance. Absorption is being immersed and pleasantly engrossed in one's work, which makes time pass quickly and causes one to have difficulties with detaching an engaging activity (Schaufeli, Salanova, González-Romá, \& Bakker, 2002b). According to Hallberg and Schaufeli (2006), engagement is a positive state of well-being or fulfillment. When engaged, employees have high levels of energy, are enthusiastic about, and show strong identification with their work (Bakker, Schaufeli, Leiter, \& Taris, 2008; Maslach, Schaufeli, \& Leiter., 2001). Based on the Job Demands and Resources Model (JD-R), engagement involves a balance between the demands of a particular situation and the available resources to meet these demands. Adequate resources to meet demands can promote engagement, while excessive demands and limited resources lead to burnout (Bakker \& Demerouti, 2007; Schaufeli \& Bakker, 2004; Schaufeli, Bakker, \& Van Rhennen, 2009)

Engagement has been studied extensively in the work context, and there is strong empirical support for its relationship with job performance, profitability, and other important work outcomes (Harter, Schmidt, \& Hayes, 2002). Engagement was also extended to the academic 
context and conceptualized in relation to students' tasks and activities (Schaufeli, Martínez, Marques-Pinto, Salanova, \& Bakker, 2002a). Engaged students feel energetic, identify strongly with their studies and are deeply involved in their academic life. Only few studies exist about the relationship between academic engagement and academic performance but, overall, these studies corroborate the results that have been found for employees, engagement being positively related to performance. For instance, Schaufeli et al., (2002a) showed that engaged university students who are energetic and immersed in their studies, are more successful. A positive relationship between engagement and performance was also found in an experimental study with students performing a group task. More engaged student groups had higher group performance (Salanova, et al., 2003). Moreover, consistent with JD-R, engagement was found to mediate the relationship between obstacles (demands) and psychosocial facilitating factors (resources) on one hand, and academic performance on another (Salanova, et al., 2010). Interestingly, although the presence of obstacles and the absence of facilitators were also related to burnout, burnout was not related to academic performance in this study, pointing to the relative importance of engagement.

In addition to this approach to academic engagement that is rooted in Europe, a different North American approach conceptualizing academic engagement as encompassing behavioral, cognitive and affective dimensions has also found strong positive associations among academic engagement and academic achievement (Cadima, Marques-Pinto, Lima, Rego, \& Pereira, 2016). For instance, a recent longitudinal study by Reeve and Lee (2014) showed that classroom engagement predicts longitudinal changes in motivations, psychological need satisfaction and self-efficacy, and also in course achievement.

Thus, research to-date supports that students who approach their studies with engagement are likely to be more successful. They deploy their resources effectively to meet the challenges 
and demands posed by academics. They may feel stressed or burned out, but these negative aspects are less likely to compromise their performance. In line with these research findings to date, we hypothesize the following:

Hypothesis 2. Academic engagement is positively related to academic performance.

\section{Engagement and Psychological Capital}

In addition to the proposed favorable effects of engagement and PsyCap on academic performance, we aim to examine more closely the interrelationship between engagement and PsyCap as antecedents of academic performance. COR theory (Hobfoll, 2002) emphasizes the 'gain spirals' associated with the attainment and preservation of resources as central to human functioning (Hobfoll \& Shirom, 2000). Accordingly, engaged students may be in a better position to invest their psychological resources such as PsyCap in a manner that can lead to positive outcomes such as academic performance. On the other hand, the possibility of gain spirals between psychological resources and engagement entails that they may mutually foster each other (Hakanen \& Roodt, 2010; Hobfoll \& Shirom, 2000). When resources are available, the level of engagement may be fostered, and this may enhance the likelihood of taking advantage of the current resources and being able to create new ones. This notion may explain why people tend to invest more resources in positive endeavors (Salanova et al., 2010) and consequently experience better performance (Bakker, 2009). Thus, the relationship between engagement and PsyCap may be reciprocal.

To further examine the direction of causality between engagement and PsyCap, we test two competing hypotheses. On one hand, we examine PsyCap as a proximal antecedent of academic performance, and a mediator of the relationship between engagement and performance. On the 
other hand, we examine PsyCap as a distal antecedent, with engagement mediating the relationship between PsyCap and performance. We offer competing arguments for these two alternative perspectives, which we then test empirically.

Engagement as an antecedent of PsyCap. Engagement has been conceptualized as a positive experience in itself (Schaufeli et al., 2002b) and able to build and facilitate task-related and personal resources (Bakker \& Demerouti, 2007; Hakanen, Schaufeli \& Ahola, 2008). Research shows that engaged employees use resources such as optimism, self-efficacy, resilience and an active coping style to assist them in managing their tasks more successfully (Bakker \& Demerouti, 2008; Luthans, Norman, Avolio \& Avey, 2008). The idea that engagement can enhance resources is consistent with the BBM (Fredrickson, 2001), as a primary premise of this model is that positive emotions broaden people's momentary thought-action repertories and build their personal resources, including physical, intellectual, social and psychological resources (Fredrickson and Branigan, 2005; Fredrickson, 2001). Accordingly, positive experiences, such as engagement, can build people's personal resources, such as PsyCap. It follows that the positive thoughts and emotions that academic engagement can produce in students can help build their psychological resources such as PsyCap over time, which in turn can be deployed toward higher academic performance as discussed earlier.

Furthermore, the vigor, dedication, and absorption components of engagement can facilitate the positive cognitive appraisals underlying PsyCap (Luthans, et al., 2007). Specifically, students who experience vigor, dedication, and absorption in relation to their academic studies may appraise their experiences and probability of success more positively, which can promote more agentic and intentional goal pursuit. In addition, in line with SCT, key mechanisms for developing PsyCap, particularly efficacy, include mastery experiences and physical and 
psychological arousal (Bandura, 1997), both of which are conceptually consistent with vigor, dedication, and absorption. Thus, engagement can be instrumental in promoting PsyCap.

Empirically, De Wall and Pienaar (2013) investigated the causal relationship between PsyCap and work engagement through a longitudinal and cross-lagged research design. Results showed that PsyCap at Time 1 did not predict engagement at Time 2, but engagement at Time 1 predicted PsyCap at Time 2. These findings are consistent with the notion that engagement can facilitate the mobilization of task and personal resources (Bakker \& Demerouti, 2007; Hakanen et al., 2008). Cordery (2007) also found engagement to predict hope, optimism and self-efficacy. Luthans (2012) and colleagues (Avey, 2014; Avey, Luthans \& Mhatre, 2008; Avey et al., 2011; Sweetman \& Luthans, 2010) have called for more research into the antecedents of PsyCap. Examining engagement as one of these antecedents can be a step in that direction. Thus, the following is hypothesized:

Hypothesis 3. Academic PsyCap mediates the relationship between academic engagement and academic performance.

PsyCap as an antecedent of engagement. In line with COR theory, as discussed earlier, it is also plausible that PsyCap promotes engagement, for several reasons. First, resources are important antecedents of engagement (Bakker \& Demerouti, 2007; Schaufeli \& Bakker, 2004). Psychological resources such as PsyCap can play an important role in meeting demanding situations such as those encountered by college students, which can contribute to their engagement. Furthermore, PsyCap can shape students' appraisals of the demands of their situations. When high PsyCap students appraise challenges more favorably, they can perceive these situations to be less demanding in relation to their personal resources. Perceived balance between demands and resources is vital for engagement. In contrast, low PsyCap students lack 
personal resources, and are also likely to appraise their situations less favorably as more demanding than their high PsyCap counterparts. Facing higher perceived demands with fewer resources is likely to result in burnout, rather than engagement.

Individual PsyCap resources can also contribute to specific dimensions of engagement. For example, hope's agentic determination to achieve goals can be linked to vigor and dedication. When hopeful students are agentically pursuing their academic goals, they are likely to do so with vigor and dedication, investing more energy and resources, unlike their less hopeful counterparts who may be 'going through the motions.' Similarly, efficacy can promote vigor, dedication and absorption as efficacious students believe in their abilities and energetically and persistently pursue challenging goals. The sense of mastery associated with efficacy can make tasks more enjoyable to engage in with vigor, dedication, and absorption. Again, the physiological and psychological arousal mechanisms of efficacy can promote vigor and energy, making more physical, cognitive and affective resources available for active engagement (Sweetman \& Luthans, 2010; Youssef-Morgan \& Bockorny, 2014).

Resilience can also be a valuable personal resource that can help students maintain engagement when faced with setbacks or challenges, through facilitating the necessary balance with task demands. It can also promote engagement through increasing vigor and dedication. When resilient students experience obstacles, they can harness their perseverence to regain confidence and try again (Sweetman and Luthans, 2010). Resilient individuals can endure and remain engaged even in situations where their less resilient counterparts may experience burnout and give up (Bakker, Demerouti, \& Euwema, 2005).

Finally, consistent with BBM, the positive outlook of optimism can facilitate the cognitive and affective resource availability necessary for active engagement. Optimism can 
enhance vigor and ward off burnout by mitigating negative spirals and detrimental cognitive processes such as cynicism, self-blame and debilitating self-talk (Sweetman \& Luthans, 2010; Youssef-Morgan \& Bockorny, 2014), which students commonly experience when they face new and unfamiliar challenges alone, away from their friends, family, and the safety of other familiar life circumstances. In contrast, lack of efficacy, hope, optimism, and resilience may discourage students from being actively engaged in their studies. Instead, when college life gets challenging, they may resort to passively going through the motions of their academic tasks. They may also misdirect their energy, resources, vigor, dedication, and absorption toward counterproductive behaviors such as excessive partying, drinking, drug use, and others, to the detriment of their academic performance. Thus, the following competing hypothesis is offered:

Hypothesis 3.1. Academic engagement mediates the relationship between academic PsyCap and academic performance.

\section{METHODS}

\section{Sample and procedures}

High rates of failure and drop-out have been identified as serious problems for higher education students all over the world, including Spain (Cabrera, Bethencourt, Alvarez Pérez, \& González Afonso, 2006) and Portugal (GPEARI - MCTES, 2008). This study was conducted in two public Universities, one in Spain and another in Portugal. The Faculty's local ethics committee (comparable to IRB) granted approval for this study. The data collection was carried out in May and June 2014. We recruited undergraduate psychology students from the University of Lisbon, Portugal and Jaume I, Spain. In Spain the questionnaires were answered in paper-pencil format. In Portugal the questionnaires were answered on-line. Students were told that the questionnaire was related to various aspects of their student life, and that there are no right or wrong answers. Students in both universities are 
familiar with this type of questionnaires. Students also signed an informed consent to give researchers access to their grades. The questionnaire required about $15 \mathrm{~min}$ to complete.

Participation was voluntary. Students did not receive any compensation for participation. From a population of 522 Portuguese students, 294 questionnaires (56.32\%) were collected. After excluding 51 incomplete questionnaires, the final sample consisted of 243 questionnaires. From a population of 479 Spanish students, 389 questionnaires (81.21\%) were collected. All students accepted the use of their grades for the study.

\section{Measures}

Academic Engagement, was measured by the Short Utrecht Work Engagement Scale (Schaufeli, Bakker \& Salanova, 2006) which contains three dimensions (vigor, dedication and absorption). The vigor, dedication, and absorption dimensions were each measured by three items (item examples include “When I'm doing my work as a student, I feel bursting with energy.", "My studies inspire me.", and "I am immersed in my studies."). All items were rated on a seven-point Likert scale that ranged from 0 (never) to 6 (every day). In this study, the Exploratory Factor Analysis showed a one-factor solution that explained $49.80 \%$ and $57.56 \%$ of the variance in the Spanish and the Portuguese samples, respectively. All items had factor loadings ranging from .52 to .78 and from .71 to .81 and good reliability (Cronbach's alpha $=.87$ and .91) on Spanish and Portuguese samples, respectively. This one-dimensional work engagement concept was also used in previous studies (e.g., Halbesleben \& Wheeler, 2008; Sonnentag, Dormann, \& Demerouti, 2010).

Psychological Capital was measured with a translated and adapted short version (twelveitem) of the Psychological Capital Questionnaire (PCQ-12) developed by Luthans, et al. (2007). The questionnaire was translated into Spanish and Portuguese according to the guidelines of Brislin (1980). Subsequently, both questionnaires phrasing was adapted to students. This scale 
includes four dimensions: efficacy (3 items, e.g. "I feel confident contributing to discussions about strategies on my studies."); hope (4 items, e.g. "I can think of many ways to reach my current goals regarding my studies."); resilience (3 items, e.g. "I usually take stressful things in stride with regard to my studies."); optimism (2 items, e.g. "I'm optimistic about what will happen to me in the future as it pertains to my studies."). Participants were asked to indicate the extent to which they agreed with the twelve statements on a seven-point scale from 0 (strongly disagree) to 6 (strongly agree). The factorial structure of the PsyCap was evaluated using an exploratory factor analysis. One factor was extracted, explaining $38.06 \%$ and $44.75 \%$ of the variance and factor loadings of the matrix structure ranged from .45 to .73 and .46 to .77 on Spanish and Portuguese samples, respectively. In this study Cronbach's alphas were .83 and .88 on Spanish and Portuguese samples, respectively.

Academic performance was assessed by the Grade Point Average (GPA), provided by the Universities at the end of the exam period, 4 or 5 months after the submission of the questionnaire. According to Spanish and Portuguese system of qualifications, GPA ranged from 5 (poor) to 10 (excellent), and from 10 (poor) to 20 (excellent), respectively. To enhance comparability, we transformed Portuguese GPAs to a 0-10 scale

\section{Data analyses}

The first stage involved carrying out descriptive analyses (mean, averages standard deviations), analysis of variance (ANOVA) to study differences between both samples and correlational analyses between variables, using the SPSS 22.0. Secondly, since this study used self-reported measures of academic engagement and PsyCap, Podsakoff, MacKenzie, Lee, and Podsakoff (2003) recommendations were taken into account to test for common method variance. 
Harman's single factor test with CFA (e.g. Iverson \& Maguire, 2000) was computed for the variables in the study.

Thirdly, AMOS 19.0 (Arbuckle, 1997) was employed to implement SEM methods using Maximum Likelihood Estimation to test the relationships between variables. Following Mathieu and Taylor (2006), we started by testing the direct paths from the Independent Variable (Academic Engagement in Model 1; Academic PsyCap in Model 2), to the Dependent Variable (Academic Performance). Testing mediation, we tested two full-mediation models (Model 3 and Model 5) with direct structural paths from Independent Variable (Academic Engagement in Model 3; PsyCap in Model 5) to the Mediators (PsyCap in Model 3; Academic Engagement in Model 5), and from Mediator to Dependent Variable (Academic Performance). Models 4 and Model 6 were partial-mediation models, where structural paths from Independent Variable (Academic Engagement in Model 4; PsyCap in Model 6) to Dependent Variable (Academic Performance) were added to the previous model. SEM analyses derive from nested model comparisons, allowing us to hone in on the specific parameters of interest and to contrast a given pattern of effects against viable alternatives.

The models were compared based on chi-square difference tests and other fit indices: namely the Comparative Fit Index (CFI), Incremental Fit Index (IFI), Root Mean Square Error of Approximation (RMSEA), and Standardized Root Means Square Residuals (SRMR). Levels of .90 or higher for CFI and IFI indicate good fit. RMSEA of .05 or lower in combination with SRMR values below .09 indicate excellent fit, whereas values below .08 and .10, respectively, indicate good fit (Byrne, 2010). The different competing models were compared by means of the $\chi 2$ difference test.

\section{RESULTS}




\section{Confirmatory Factor Analysis}

The measurement model with two latent factors (i.e. academic engagement and psychological capital) corresponding to our Theoretical Model showed an acceptable fit $\left[\chi^{2}\right.$ $(180)=378.47, p<.01, \mathrm{SRMR}=.05, \mathrm{CFI}=.94, \mathrm{IFI}=.94, \mathrm{RMSEA}=.05 ; \chi^{2}(180)=431.70, p$ $<.01, \mathrm{SRMR}=.06, \mathrm{CFI}=.91, \mathrm{IFI}=.91, \mathrm{RMSEA}=08$, on Spanish and Portuguese samples, respectively]. In comparison with an alternative tested one-factor model - where all items loaded on a single latent variable - an unacceptable fit of the latter was verified $\left[\chi^{2}(181)=611.94, p\right.$ $<.01, \mathrm{SRMR}=.07, \mathrm{CFI}=.86, \mathrm{IFI}=.86, \mathrm{RMSEA}=.08 ; \chi^{2}(181)=599.39, p<.01 ; \mathrm{SRMR}=.08$, $\mathrm{CFI}=.84, \mathrm{IFI}=.85, \mathrm{RMSEA}=.10$, on Spanish and Portuguese samples, respectively]. Furthermore, the difference between our theoretical model and the one-factor model was significant $\left(\Delta \chi^{2}(1)=233.47, p<.01 ; \Delta \chi^{2}(1)=167.69, p<.01\right.$ on Spanish and Portuguese samples, respectively) and confirmed that our theoretical model represented the best fit for both samples.

\section{Descriptive Statistics}

The means, standard deviations and correlation matrix are presented in Table 1.

Considering the results of both samples, Spanish students presented higher scores on academic engagement $(M=4.01, S D=.86 ; M=3.47, S D=.95$, on Spanish and Portuguese samples respectively, considering a seven point Likert scale), as well as on PsyCap $(M=4.15, S D=.80$; $M=4.09, S D=.95)$ than Portuguese students. Analyzing the inter-correlations among the studied variables (see also Table 1) we found positive relationships between all variables in each sample.

Insert Table 1 about here

Analysis of variance (ANOVA) to study differences between samples (Portuguese and Spanish), showed significant differences in engagement $(\mathrm{F}=55.49, \mathrm{p}<.000)$ and academic 
performance $(\mathrm{F}=10.52, \mathrm{p}<.001)$, with Spanish students showing significantly higher levels of engagement and Portuguese students significantly higher academic performance. There are no significant differences in PsyCap.

\section{Structural Equation Models}

As shown in Table 2, the direct path models (Models 1 and 2) did not fit the data well, which supports the importance of including paths leading to or stemming from the mediator (Mathieu and Taylor, 2006). Furthermore, significant direct associations were found between academic engagement and academic performance (Spanish sample: $\beta=.19 p<0.01, B=.16$, SE $=.05$; Portuguese sample: $\beta=.15, \mathrm{p}<0.01, \mathrm{~B}=.26, \mathrm{SE}=.12)$ and between PsyCap and academic performance (Spanish sample: $\beta=.32, \mathrm{p}<0.01, \mathrm{~B}=.36 \mathrm{SE}=.07$; Portuguese sample: $\beta=.21, \mathrm{p}<0.01, \mathrm{~B}=.32, \mathrm{SE}=.10)$. Thus Hypotheses 1 and 2 were supported.

\section{Insert Table 2 about here}

Our next step was to test which mediated model (partial or full mediation) better fit the data for each sample. As shown in Table 2, Model 3 (full mediation of the relationship between academic engagement and academic performance by PsyCap) showed an acceptable fit. Model 4 (partial mediation, including the direct path from academic engagement to academic performance) also provided an adequate fit for the data for both samples. Thus, Hypothesis 3 was supported. We then compared the partial and full mediation models and observed that they did not differ significantly (Spanish sample: $\Delta \chi^{2}(1)=0.53$, n.s. ; Portuguese sample: $\Delta \chi^{2}(1)=1.09$, n.s.). Therefore, the full mediation model (Model 3) was favored because it is more parsimonious, and had the lowest AIC values. The standardized and unstandardized regression coefficients and standard errors are shown in Figure 2. As shown in Figure 2b, the direct path from academic 
engagement to academic performance in Model 4 was not significant in either sample, supporting full mediation (Model 3).

Insert Figure 2 about here

Additionally, in order to test hypothesis 3.1 (the reverse-causal relationship between academic engagement and PsyCap), we tested another set of full (Model 5) and partial (Model 6) mediation models, with academic engagement mediating the relationship between PsyCap and academic performance. As shown in Table 2, these two models also showed adequate fit in both samples. Thus, the reverse-causal relationship is also plausible, and Hypothesis 3.1 was supported. However, when comparing the partial and full mediation models, they differed significantly (Spanish sample: $\Delta \chi^{2}(1)=16.93, \mathrm{p}<.001$; Portuguese sample: $\Delta \chi^{2}(1)=3.98, \mathrm{p}$ $<.05)$. The partial mediation model (Model 6) was more favorable based on fit indices because it had the lower chi-square and AIC values. However, as shown in Figure 2, the path from academic engagement to academic performance was not significant. On the other hand, both paths of the full mediation model (Model 5) were significant, thus favoring full mediation and supporting Hypothesis 3.1 .

The final step was to compare Models 3 and 4 to Models 5 and 6 in order to determine the most likely causal sequence. When the models to be compared are not nested, a fit index to compare the fit of statistical models is AIC (Akaike, 1987; Kline, 2011). Model 3 was the model that showed the lowest AIC value, supporting Hypothesis 3. Thus, the relationship between academic engagement and academic performance is fully mediated by PsyCap. The model explained $45 \%$ of psychological capital and $10 \%$ of academic performance on Spanish sample, and 58\% of psychological capital and 5\% of academic performance on Portuguese sample. Sobel 
test was also used to further examine Model 3. The results supported full mediation $(Z=4.38, p$ $<.01$ and $Z=2.89, p<.01$ on Spanish and Portuguese samples, respectively). Finally, multigroup analysis that included both samples in order to inspect invariance between the two groups of participants were performed. We found significant differences between the two samples in the relationship between academic engagement and PsyCap (Z Spanish vs Portuguese $=3.17$, $\mathrm{p}<.01)$, but not between PsyCap and academic performance (Z Spanish vs Portuguese $=.19$, n.s.).

\section{DISCUSSION}

The purpose of this study was to examine the role of psychological factors, namely academic engagement and PsyCap, as predictors of academic performance. Drawing from Conservation of Resources theory (COR; Hobfoll, 2002), Social Cognitive Theory (SCT; Bandura, 1986), and the Broaden-and-Build Model (BBM, Fredrickson, 2001), these two antecedents were conceptualized and empirically tested.

Furthermore, PsyCap, was explored as a mediating mechanism that may explain how students capitalize on their academic engagement to achieve higher academic performance. Specifically, the vigor, dedication, and absorption dimensions of academic engagement can promote positive spirals of psychological resource building, replenishment, and deployment, as well as PsyCap's positive cognitive appraisals that facilitate motivation, effort, and ultimately performance.

Alternatively, a competing model was also examined, in which academic engagement mediates the relationship between PsyCap and academic performance. Consistent with the Job Demands and Resources (JD-R) model, psychological resources may help balance the demands and challenges of academic life, or at least allow students to appraise them as more manageable, 
which can facilitate engagement and in turn high performance. Furthermore, the positive dimensions of PsyCap such as efficacy, hope, optimism, and resilience can also trigger active and intentional engagement in academic goal setting and goal pursuit with vigor, dedication, and absorption, which can enhance the probability of high academic performance.

Results of the SEM analysis across two samples support our hypotheses that college students' academic engagement positively relates to their psychological resources (PsyCap), which in turn are positively related to their academic performance. Furthermore, and of special relevance, SEM results also show that college students' PsyCap mediates the effects of academic engagement on academic performance. It is also plausible that academic engagement mediates the relationship between PsyCap and academic performance. However, among six alternative models examined in two samples, PsyCap as a full mediator of the relationship between academic engagement and academic performance was the model that received the strongest support.

Taken together these findings offer important contributions to theory, research and practice regarding academic performance. First, as discussed in detail in the introduction, traditional predictors of academic performance such as high school grades and admission tests, currently the main factors considered both in North America, Europe, and around the world (Richardson, et al., 2012, Trapmann, Hell, Hirn, \& Schuler, 2007), are becoming increasingly ineffective, as evidenced by the dismal college completion rates. These trends point to the need for a wider range of predictors of academic performance. Our results indicate that psychological factors such as academic engagement and personal resources (PsyCap) are important predictors of academic performance. These results are also consistent with other studies with students (e.g. Enright \& Gitomer, 1989; Luthans, et al., 2012; Luthans, et al., 2014; Oswald et al., 2004; 
Salanova et al.,2010, Zajacova, et al., 2005). Thus our results broaden the knowledge of antecedents of academic performance and encourage academic researchers, educators, and administrators to pay further attention to these psychological factors.

Second, this study supports and extends previous research on the interrelationships between engagement, PsyCap, and performance (e.g. Luthans et al., 2012; De Wall \& Pienaar, 2013; Siu et al., 2013), which supports PsyCap as a mediator in the engagement - performance relationship. This result contributes to the theoretical understanding and empirical support regarding the antecedents of PsyCap (Avey, 2014), the conditions in which PsyCap may be manifested, and the mechanisms through which engagement operates to promote success, particularly in the context of academic studies. Specifically, more engaged students are more likely to experience higher levels of PsyCap, which in turn positively impacts their performance.

\section{Strengths and Limitations}

This study has some notable strengths. First, large sample size increases the statistical power of this study. Second, drawing samples from different universities in two different countries, both of which are outside the United States where most of the previous research on PsyCap has taken place, adds to the external validity of the findings. Similarly, most of the research on engagement and PsyCap to-date focuses on the workplace. Examining these variables in the context of academic performance tests the boundaries of existing theories. Finally, utilizing objective academic performance outcomes collected from different sources and at different points in time (GPA based on grades assigned by multiple professors in multiple classes) is a strong point of this study. It adds to the robustness of our findings and reduces common-source and common-method biases (Podsakoff et al., 2003). 
On the other hand, this study also has several limitations. First, a convenience sample was used, which may have introduced selection biases that can compromise the generalizability of the results. Second, academic engagement and PsyCap data were obtained through self-report measures, which may have caused common-method bias (Podsakoff, et al., 2003). However, our findings were in line with theoretical predictions and earlier findings, and Harman's one-factor test suggests that common method variance should not be a serious threat in our study. Third, data are cross-sectional. Although SEM analysis provides some information about the possible direction of the relationships, and testing competing hypotheses provided empirical support for the proposed model, cross-sectional study designs do not allow one to draw firm conclusions regarding the causal ordering among the variables studied. Finally, there are many factors for this study did not account, including personality, socioeconomic factors, and traditional predictors of academic performance, all of which could have been contributing factors. However, this data was not accessible for the study samples.

\section{Implications for Future Research}

This study provides important theoretical and empirical contributions to the knowledge on variables and mechanisms that contribute to the academic performance of college students, namely the mediating role of PsyCap in the academic engagement - performance relationship. Future research should examine these relationships longitudinally and experimentally to ascertain magnitude and causal direction. Furthermore, research should examine these psychological antecedents alongside traditional predictors of academic performance such as high school academic performance, entrance exams, extracurricular activities, and others. Future research should also control for personality traits such as cognitive mental abilities (i.e., intelligence; Schmidt, 2009), the Big Five personality traits (conscientiousness, extroversion, 
emotional stability, agreeableness, and openness to experience; Barrick \& Mount, 1991), core self-evaluations (generalized self-efficacy, self-esteem, neuroticism, and locus of control; Judge \& Bono, 2001) all of which have been supported in past research as important predictors of performance. Including traditional and trait antecedents as control variables can help determine the relative contributions of psychological predictors such as engagement and PsyCap.

Additionally, engagement and PsyCap may interact meaningfully with these predictors. They may make their relationships with performance stronger, highlighting the multiplicative role of traditional, personality, and psychological factors. For example, alternatively, they may buffer these relationships such that psychological predictors may neutralize or substitute for traditional or personality antecedents. For example, engagement or PsyCap may "make up" for low scores on standardized tests. Future research should examine these competing hypotheses to determine the interactive role of various predictors of academic performance

\section{Implications for Practice}

Unlike many trait predictors of academic performance (and success in general) such as intelligence and personality, PsyCap and engagement are "state-like" (Luthans, et al., 2007). This means that they are malleable enough to be open to development, yet more stable and persistent than momentary states such as fleeting moods and emotions. Research in the work context has shown that organizations can actively stimulate work engagement by optimizing employees' job demands and job resources (Bakker, 2015). PsyCap can also be developed through targeted interventions (Dello Russo \& Stoykova, 2015; Demerouti, Erick, Snelder, \& Wild, 2011; Ertosun, Erdil, Deniz, \& Lutfihak, 2015; Luthans, et al., 2014; Luthans et al., 2006; Luthans, Avey, Avolio, \& Peterson, 2010; Luthans, Avey, \& Patera, 2008). Furthermore, employees may also proactively 
"craft" job and personal characteristics to influence their own work engagement and PsyCap (Bakker, 2015).

Teachers, parents, mentors, and academic administrators should take these evidencebased findings into consideration in the development processes they utilize to prepare students for college. Instead of only focusing on academics and test scores, they should also incorporate development interventions to promote students' academic engagement and PsyCap, in order to foster their academic performance. Fortunately, these development interventions are inexpensive, effective, relatively easy to implement, and do not require special innate abilities. In addition, development of academic engagement and PsyCap should be ongoing in order to boost students' motivation and morale as they face the day-to-day challenges of academic life.

Engagement and PsyCap hold promise in terms of predicting and promoting academic performance. The time may have come to incorporate psychological factors such as these in college selection criteria. Indeed, students who approach their academic goals with vigor, dedication, and absorption are more likely to be confident, hopeful, optimistic, and resilient. They are more likely to believe in themselves and their chances of success, and to invest the necessary time, energy, and motivation to achieve their goals and conquer challenges. These psychological factors may prove to be at least as important as, if not more important than innate cognitive abilities, personality traits, or standardized test scores, in predicting academic performance. 


\section{REFERENCES}

Adelman, C. (2006). The toolbox revisited: Paths to degree completion from high school through college. Washington, DC. U.S: Department of Education.

Arce, M., Crespo, B., \& Míguez-Álvarez, C. (2015). Higher education drop-out in Spainparticular case of universities in Galicia. International Education Studies, 8, 247-264. http://dx.doi.org/10.5539/ies.v8n5p247

Avey, J. B. (2014). The left side of psychological capital: New evidence on the antecedents of PsyCap. Journal of Leadership \& Organizational Studies, 21, 141-149. Doi:

\section{$10.1177 / 1548051813515516$}

Avey, J. B., Luthans, F., \& Mhatre, K. H. (2008). A call for longitudinal research in positive organizational behavior. Journal of Organizational Behavior, 29, 705-711. http://digitalcommons.unl.edu/leadershipfacpub/7

Avey, J. B., Reichard, R. J., Luthans, F., \& Mhatre, K. H. (2011). Meta-analysis of the impact of positive psychological capital on employee attitudes, behaviors, and performance. Human Resource Development Quarterly, 22, 127-152. Doi: 10.1002/hrdq.20070

Avolio, B. J., \& Luthans, F. (2006). The high impact leader: Moments matter for accelerating authentic leadership development. New York: McGraw-Hill.

Bakker, A. B. (2009). Building engagement in the workplace. In C. L. Cooper \& R. J. Burke (Eds.), The peak performing organization (pp. 50-72). Oxon UK: Routledge.

Bakker, A.B. (2015). A Job Demands Resources approach to public service motivation. Public Administration Review, 75, 723-732. Doi 10.1111/puar.12388

Bakker, A.B., \& Demerouti, E. (2007). The job demands-resources model: State of the art. Journal of Managerial Psychology, 22, 309-328. Doi 10.1108/02683940710733115 
Bakker, A.B., \& Demerouti, E. (2008). Towards a model of work engagement. Career Development International, 13, 209-223. Doi 10.1108/13620430810870476

Bakker, A.B., Demerouti, E., \& Euwema, M.C. (2005). Job resources buffer the impact of job demands on burnout. Journal of Occupational Health Psychology, 10, 170-180. Doi $10.1037 / 1076-8998 \cdot 10.2 \cdot 170$

Bakker, A.B., Sanz Vergel, A.I., \& Kuntze, J. (2015). Student engagement and performance: A weekly diary study on the role of openness. Motivation and Emotion, 39, 49-62. Doi $10.1007 / \mathrm{s} 11031-014-9422-5$

Bakker, A. B., Schaufeli, W. B., Leiter, M. P., \& Taris, T. W. (2008). Work engagement: An emerging concept in occupational health psychology. Work and Stress, 22, 187-200. Doi $0.1080 / 02678370802393649$

Bandura, A. (1986). Social foundations of thought and action: A social cognitive theory. Englewood Cliffs, NJ: Prentice Hall.

Bandura, A. (1997). Self-efficacy: The exercise of control. New York: Freeman.

Bandura, A. (2001). Social cognitive theory: An agentic perspective. Annual Review of Psychology, 52, 1-26. Doi 10.1146/annurev.psych.52.1.1

Bandura, A. (2012). On the functional properties of perceived self-efficacy revisited. Journal of Management, 38, 9-44. Doi 10.1177/0149206311410606

Bandura, A., \& Locke, E. A. (2003). Negative self-efficacy and goal effects revisited. Journal of Applied Psychology, 88, 87-99. Doi 10.1037/0021-9010.88.1.87

Baron, R.M., \& Kenny, D.A. (1986). The moderator-mediator variable distinction in social psychological research: Conceptual, strategical and statistical considerations. Journal of Personality and Social Psychology, 51, 1173-1182. 
Barrick, M.R., \& Mount, M.K. (1991). The big five personality dimensions and job performance: A meta-analysis. Personnel Psychology, 44, 1-26.

Byrne, B. M. (2010). Structural Equation Modeling with AMOS. New York, NY: Routledge.

Brislin, R.W. (1980). Translation and Content Analysis of Oral and Written Material. In: H.C. Triandis and J.W. Berry (Eds.), Handbook of Cross-Cultural Psychology (pp. 389-444). Boston: Allyn \& Bacon.

Cabrera, L., Bethencourt, J. T., Álvarez Pérez, P., \& González Afonso, M. (2006). The dropout problem in University Study. Relieve, 12, 2. http://www.uv.es/RELIEVE/v12n2/RELIEVEv12n2_1.htm

Cabrera, A. F., \& La Nasa, S. M. (2000). Understanding the college choice of disadvantaged students. New directions for institutional research, 107, 5-22.

Cadima, I., Marques-Pinto, A., Lima, S., Rego, S., Pereira, J., \& Ribeiro, I. (2016). Well-being and academic achievement in secondary school pupils: The unique effects of burnout and engagement. Journal of Adolescence, 53, 169-179. Doi

$\underline{10.1016 / \text { j.adolescence.2016.10.003 }}$

Cameron K., \& Spreitzer, G.M. (2012). Oxford handbook of positive organizational scholarship. New York: Oxford University Press.

Carver, C.S., Scheier, M.F., Miller, C.J., \& Fulford, D. (2009). Optimism. In S.J. Lopez \& C.R. Snyder (Eds.), Oxford Handbook of Positive Psychology, 2nd Edition (pp. 303-311). Oxford: Oxford University Press.

Chambel, M. J., \& Curral, L. (2005). Stress in Academic Life: Work Characteristics as Predictors of Student Well-being and Performance. Applied Psychology: an International Review, 54, 135-147. Doi 10.1080/01443410.2013.857010 
Cordery, J. (2007). Accentuating the positive. Building hope, optimism, confidence and resilience in organisations. Wembley, Western Australia: Australian Institute of Management.

Cotton, S. J., Dollard, M. F., \& de Jonge, J. (2002). Stress and student job design: Satisfaction, well-being, and performance in university students. International Journal of Stress Management, 9, 147-162. Doi 10.1023/A:1015515714410

Curry, L.A., Snyder, C.R., Cook, D.I., Ruby, B.C., \& Rehm, M. (1997). The role of hope in student-athlete academic and sport achievement. Journal of Personality and Social Psychology, 73,1257-1267.

Dello Russo, S., \& Stoykova, P. (2015). Psychological Capital Intervention (PCI): A Replication and Extension. Human Resource Development Quarterly, 26, 329-347. Doi 10.1002/hrdq. 21212

Demerouti, E., Erik, V. E., Snelder, M., \& Wild, U. (2011). Assessing the effects of a "personal effectiveness" training on psychological capital, assertiveness and self-awareness using self-other agreement. Career Development International, 16, 60-81.

Enright, M. L., \& Gitomer, D. (1989). Toward a description of successful graduate students (GRE Boards Report No. 85-17R). Princeton, NJ: Educational Testing Service. https://www.ets.org/Media/Research/pdf/RR-89-09-Enright.pdf

Ertosun, O.Z., Erdil, O., Deniz, N., \& Lutfihak, A. (2015). Positive psychological capital development: A field study by the Solomon four group design. International Business Research, 8, 102-111.

Federal Reserve System (2015). How much student debt is out there?. Retrieved August 11, 2016 from: http://www.federalreserve.gov/econresdata/notes/feds-notes/2015/how-muchstudent-debt-is-out-there-20150807.html 
Running head: ENGAGEMENT, PSYCHOLOGICAL CAPITAL AND PERFORMANCE 36

Fredrickson, B.L. (2001). The role of positive emotions in positive psychology: The broadenand-build theory of positive emotions. American Psychologist, 56, 218-226. https://www.ncbi.nlm.nih.gov/pmc/articles/PMC3122271/

Fredrickson, B.L., \& Branigan, C. (2005). Positive Emotions Broaden the Scope of Attention and Thought-Action Repertoires. Cognition and Emotion, 19, 313-332. Doi $10.1080 / 02699930441000238$

Fry, R. 2012. A record one-in-five households now owe student loan debt. Retrieved August 11, 2016 from: http://www.pewsocialtrends.org/2012/09/26/a-record-one-in-five-householdsnow-owe-student-loan-debt/

Halbesleben, J. R. B., \& Wheeler, A. R. (2008). The relative roles of engagement and embeddedness in predicting job performance and intention to leave. Work \& Stress, 22, 242-256. Doi 10.1080/02678370802383962

Hallberg, U., \& Schaufeli, W. B. (2006). "Same same" but different? Can work engagement be discriminated from job involvement and organizational commitment? European Psychologist, 11, 119-127. Doi 10.1027/1016-9040.11.2.119

Hakanen, J.J., \& Roodt, G. (2010). Using the job demands-resources model to predict engagement: Analysing a conceptual model. In A.B. Bakker, \& M.P. Leiter, (Eds.). Work Engagement, A Handbook of Essential Theory and Research (pp. 85-101). Great Britain: Psychology Press.

Hakanen, J. J., Schaufeli, W.B., \& Ahola, K. (2008). The Job Demands-Resources model: A three-year cross-lagged study of burnout, depression, commitment, and work engagement. Work Stress, 22, 224-241. Doi 10.1080/02678370802379432 
Harter, J. K., Schmidt, F. L., \& Hayes, T. L. (2002). Business-unit-level relationship between employee satisfaction, employee engagement, and business outcomes: A meta-analysis. Journal of Applied Psychology, 87, 268-279. Doi 0.1037//0021-9010.87.2.268

Hauser, D., \& Johnston, A. (2016). Public costs, relative subsidies, and repayment burdens of federal us student loan plans: Lessons for reform. Higher Education Policy, 29, 89-107. Doi 10.1057/hep.2014.25

Hobfoll, S. E. (2002). Social and psychological resources and adaptation. Review of General Psychology, 6, 307-324. Doi 10.1037/1089-2680.6.4.307

Hobfoll, S. E., Johnson, R. J., Ennis, N., \& Jackson, A. P. (2003). Resource loss, resource gain, and emotional outcomes among inner city women. Journal of Personality and Social Psychology, 84, 632-643. Doi 10.1037//0022-3514.84.3.632

Hobfoll, S. E., \& Shirom, A. (2000). Conservation of resources theory: Applications to stress and management in the workplace. In R.T. Golembiewski (Ed.) Handbook of organization behavior (pp. 57-81). New York: Dekker.

Iverson, R. D., \& Maguire, C. (2000). The relationship between job and life satisfaction: Evidence from a remote mining community. Human Relations, 53, 807-839.

James, L. R., Mulaik, S. A., \& Brett, J. M. (1982). Causal analysis: Assumptions, models and data. Beverly Hills, CA: Sage.

Jang, H., Kim, E.-J., \& Reeve, J. (2012). Longitudinal test of self determination theory's motivation mediation model in a naturally occurring classroom context. Journal of Educational Psychology, 104, 1175-1188. Doi:10.1037/a0028089

Judge, T. A., \& Bono, J. E. (2001). Relationship of core self-evaluations traits--self-esteem, generalized self-efficacy, locus of control, and emotional stability--with job satisfaction 
and job performance: A meta-analysis. Journal of Applied Psychology, 86, 80-92. Doi $10.1037 / / 0021-9010.86 .1 .80$

Kuh, G., Cruce, T., Shoupe, R., \& Kinzie, J. (2008). Unmasking the effects of student engagement on first-year college grades and persistence. Journal of Higher Education, 79, 540-563. Doi 10.1353/jhe.0.0019

Luthans, F. (2002a). The need for and meaning of positive organizational behavior. Journal of Organizational Behavior, 23, 695-706. Doi 10.1002/job.165

Luthans, F. (2002b). Positive organizational behavior: Developing and managing psychological strengths. Academy of Management Executive, 16, 57-72. Doi $10.1177 / 0149206307300814$

Luthans, F. (2012). Psychological capital development: Background, retrospective analysis and future directions. Human Resource Development Quarterly, 23, 1-8.

Luthans, B.C., Luthans, K.W., \& Avey, J.B. (2014). Building the leaders of tomorrow: The development of academic psychological capital. Journal of Leadership and Organizational Studies, 21, 191- 200.

Luthans, B.C., Luthans, K.W., \& Jensen, S. (2012). The impact of business school students' psychological capital on academic performance. Journal of Education for Business, 87, 253-259.

Luthans, F., Avey, J. B., Avolio, B. J., Norman, S. M., \& Combs, G. J. (2006). Psychological capital development: Toward a micro-intervention. Journal of Organizational Behavior, 27, 387-393. Doi 10.1002/job.373 
Luthans, F., Avey, J. B., Avolio, B. J., \& Peterson, S. (2010). The development and resulting performance impact of positive psychological capital. Human Resource Development Quarterly, 21, 41-66. Doi 10.1002/hrdq.20034

Luthans, F., Avey, J.B., \& Patera, J.L. (2008). Experimental analysis of a web-based training intervention to develop positive psychological capital. Academy of Management Learning and Education, 7, 209-221. http://digitalcommons.unl.edu/managementfacpub/135

Luthans, F., Avolio, B. J., Avey, J. B., \& Norman, S. M. (2007). Psychological capital: Measurement and relationship with performance and job satisfaction. Personnel Psychology, 60, 541-572.

Luthans, F., Luthans, K., \& Luthans, B. (2004). Positive psychological capital: Going beyond human and social capital. Business Horizons, 47, 45-50. http://digitalcommons.unl.edu/managementfacpub/145

Luthans, F. Norman, S.M., Avolio, B.J., \& Avey, J.B. (2008). The mediating role of psychological capital in the supportive organizational climate - employee performance relationship. Journal of Organizational Behavior, 29, 219-238. http://digitalcommons.unl.edu/managementfacpub/136

Luthans, F., \& Youssef, C. M. (2007). Emerging positive organizational behavior. Journal of Management, 33, 321-349. http://digitalcommons.unl.edu/leadershipfacpub/8

Luthans, F., \& Youssef, C. (2004). Human, social, and now positive psychological capital management: Investing in people for competitive advantage. Organizational Dynamics, 33, 143-160. Doi 10.1016/j.orgdyn.2004.01.003 
Luthans, F., \& Youssef-Morgan, C.M. (2016). Psychological capital: An evidence-based positive approach. Annual Review of Organizational Psychology and Organizational Behavior, in press.

Luthans, F., Youssef-Morgan, C.M., \& Avolio, B. (2015). Psychological capital and beyond. New York: Oxford University Press.

Lyubomirsky, S., King, L., \& Diener, E. (2005). The benefits of frequent positive affect: Does happiness lead to success? Psychological Bulletin, 131, 803-855. Doi 0.1037/00332909.131.6.803

Martin, A. (2009). Motivation and engagement across the academic life span: A developmental construct validity study of elementary school, high school, and university/college students. Educational and Psychological Measurement, 69, 794-824. Doi $10.1177 / 0013164409332214$

Maslach, C., Schaufeli, W.B., \& Leiter, M.P. (2001). Job burnout. Annual Review of Psychology, 52, 397-422. Doi 10.1146/annurev.psych.52.1.397

Masten, A.S. (2001). Ordinary magic. Resilience processes in development. American Psychologist, 56, 227-238. Doi 10.1037//0003-066X.56.3.227

Masten, A.S., Cutuli, J. J., Herbers, J. E, \& Reed, M.G. J. (2009). Resilience in Development. In S.J. Lopez \& C.R. Snyder (Eds.), Oxford handbook of positive psychology (2nd ed.) (pp. 117-131). New York: Oxford University Press.

Mathieu, J. E., \& Taylor, S. R. (2006). Clarifying conditions and decision points for mediational type inferences in organizational behavior. Journal of Organizational Behavior, 27, 1031-1056. doi:10.1002/ job.426. 
National Center for Education Statistics. (2016). Undergraduate retention and graduation rates. Retrieved August 11, 2016 from: http://nces.ed.gov/programs/coe/indicator_ctr.asp

Nelson, D., \& Cooper, C. L. (2007). Positive organizational behavior: Accentuating the positive at work. Thousand Oaks, CA: Sage

Nielsen, I., Newman, A., Smyth, R., Hirst, G., \& Heilemann, B. (2016). The influence of instructor support, family support and psychological capital on the well-being of postgraduate students: A moderated mediation model. Studies in Higher Education, in press.

Organization for Economic Cooperation and Development. (2015). Graduation and entry rates. Retrieved August 11, 2016 from: http://stats.oecd.org/Index.aspx?datasetcode=EAG_GRAD_ENTR_RATES\#

Oswald, F. L., Schmitt, N., Kim, B. H., Ramsay, L. J., \& Gillespie, M. A. (2004). Developing a biodata measure and situational judgment inventory as predictors of college student performance. Journal of Applied Psychology, 89, 187-207. Doi 10.1037/00219010.89 .2 .187

Pekrun, R., Elliot, A. J., \& Maier, M. A. (2006). Achievement goals and discrete achievement emotions: A theoretical model and prospective test. Journal of Educational Psychology, 98(3), 583-597. Doi 10.1037/0022-0663.98.3.583

Peterson, C. (2000). The future of optimism. American Psychologist, 55, 44-55.

Peterson, C., \& Barrett, L. (1987). Explanatory style and academic performance among university freshmen. Journal of Personality and Social Psychology, 53, 603-607.

Pintrich, P., \& de Groot, E. (1990). Motivational and self-regulated learning components of classroom academic performance. Journal of Educational Psychology, 82, 33-40. 
Podsakoff, P.M., MacKenzie, S.C., Lee, V., \& Podsakoff, N.P. (2003). Common method biases in behavioral research. Journal of Applied Psychology, 88, 879-903. Doi 10.1037/00219010.88 .5 .879

Prola, M., \& Stern, D. (1984). Optimism about college life and academic performance in college. Psychological Reports, 55, 347-350.

Rand, K. L., Martin, A. D., \& Shea, A. (2011). Hope, but not optimism, predicts academic performance of law students beyond previous academic achievement. Journal of Research in Personality, 45, 683-686.

Reeve, J., \& Lee, W. (2014). Students' classroom engagement produces longitudinal changes in classroom motivation. Journal of Educational Psychology, 106(2), 527-540. Doi

\section{$\underline{10.1037 / a 0034934}$}

Richardson, M., Abraham, C., \& Bond, R. (2012). Psychological correlates of university students' academic performance: A systematic review and meta-analysis. Psychological Bulletin, 138, 353-387. Doi 10.1037/a0026838

Salanova, M., Llorens, S., Cifre, E., Martínez, I. M., \& Schaufeli, W. (2003). Perceived collective efficacy, subjetive well-being and task performance among electronic groups. Small Group Research, 34, 43-73. Doi 10.1177/1046496402239577

Salanova, M., Schaufeli, W., Martinez, I., \& Breso, E. (2010). How obstacles and facilitators predict academic performance: The mediating role of study burnout and engagement. Anxiety, Stress, and Coping, 23, 53-70. Doi 10.1080/10615800802609965

Schaufeli, W.B., \& Bakker, A.B. (2004). Job demands, job resources, and their relationship with burnout and engagement: A multi-sample study. Journal of Organizational Behavior, 25, 293-315. Doi 10.1002/job.248 
Schaufeli, W. B., Bakker, A. B., \& Salanova, M. (2006). The measurement of work engagement with a short questionnaire: A cross-national study. Education and Psychological Measurement, 66, 701-716. Doi 10.1177/0013164405282471

Schaufeli, W.B., Bakker, A.B., \& Van Rhenen, W. (2009). How changes in job demands and resources predict burnout, work engagement, and sickness absenteeism. Journal of Organizational Behavior, 30, 893-917. Doi 10.1002/job.595

Schaufeli, W. B., Martínez, I. M., Marques-Pinto, A., Salanova, M., \& Bakker, A. (2002a). Burnout and engagement in university students. A Cross-National Study. Journal of CrossCultural Psychology, 33, 464-481.

Schaufeli, W. B., Salanova, M., Gonzalez-Roma, V., \& Bakker, A. B. (2002b). The measurement of engagement and burnout: A two sample confirmatory factor analytic approach. Journal of Happiness Studies, 3, 71-92.

Schmidt, B., \& MacWilliams, B. (2011). Admission criteria for undergraduate nursing programs: A systematic review. Nurse Educator, 36, 171-174. Doi 10.1097/NNE.0b013e31821fdb9d.

Schmidt, F. (2009). Select on intelligence. In E. Locke (Ed.), Handbook of principles of organizational behavior ( $2^{\text {nd }}$ ed.): $3-17$. West Sussex, UK: Wiley.

Schneider, S. L. (2001). In search of realistic optimism. American Psychologist, 56, 250-263. Seligman, M.E.P. (1998). Learned optimism. New York: Pocket Books.

Seligman, M.E.P., \& Csikszentmihalyi, M. (2000). Positive psychology. American Psychologist, $55,5-14$.

Siu, O. L., Bakker, A., \& Jiang, X. (2013). Psychological Capital Among University Students: Relationships with Study Engagement and Intrinsic Motivation. Journal of Happiness Studies, 15, 979-994. Doi 10.1007/s10902-013-9459-2 
Snyder, C.R. (2000). Handbook of hope. San Diego: Academic Press.

Snyder, C. R., Irving, L., \& Anderson, J. (1991). Hope and health: Measuring the will and the ways. In C. R. Snyder \& D. R. Forsyth (Eds.), Handbook of social and clinical psychology (pp. 285-305). Elmsford, NY: Pergamon.

Sonnentag, S., Dormann, C., \& Demerouti, E. (2010). Not all days are created equal: The concept of state work engagement. In A. B. Bakker \& M. P. Leiter (Eds.), Work engagement: Recent developments in theory and research (pp. 25-38). New York: Psychology Press.

Stajkovic, A.D., \& Luthans, F. (1998a). Self-efficacy and work-related performance: A metaanalysis. Psychological Bulletin, 124, 240-261.

Stajkovic, A.D., \& Luthans, F. (1998b). Social cognitive theory and self-efficacy: Going beyond traditional motivational and behavioral approaches. Organizational Dynamics, 26, 62-74.

Sweetman, D., \& Luthans, F. (2010). The power of positive psychology: psychological capital and work engagement. In Bakker \& Leiter (Eds), Work engagement: Recent developments in theory and research (pp. 54-68). New York: Psychology Press.

Trapmann, S., Hell, B., Hirn, J. W., \& Schuler, H. (2007). Meta-analysis of the relationship between the big five and academic success at university. Journal of Psychology, 215, 132-151. Doi 10.1027/0044-3409.215.2.132

Truell, A., \& Woosley, S. (2008). Admission criteria and other variables as predictors of business student graduation. College Student Journal, 42, 348-356.

U.S. Department of Education. (2013). Default rates continue to rise for federal student loans. Retrieved August 11, 2016 from: http://www.ed.gov/news/press-releases/default-rates$\underline{\text { continue-rise-federal-student-loans }}$ 
Wright, T. A. (2003). Positive organizational behavior: An idea whose time has truly come. Journal of Organizational Behavior, 24, 437-442.

Young, J., \& Korbin, J. (2001). Differential validity, differential prediction and college admission testing: A comprehensive review and analysis. Retrieved August 22, 2016 from: http://research.collegeboard.org/publications/content/2012/05/differential-validity$\underline{\text { differential-predictionand-college-admission }}$

Youssef, C.M., \& Luthans, F. (2013). Developing psychological capital in organizations: Cognitive, affective and conative contributions of happiness. In S.A. David, I. Boniwell, \& A.C. Ayers (Eds.), Oxford handbook of happiness (pp. 751-766). New York: Oxford University Press.

Youssef-Morgan, C.M., \& Bockorny, K. 2014. Engagement in the context of positive psychology. In. C. Truss, R. Delbridge, K. Alfes, A. Shantz, \& E. Soane, (Eds.), Employee engagement in theory and practice (pp. 36-56). London: Routledge.

Youssef-Morgan, C. M., \& Luthans, F. (2013). Psychological capital theory: Toward a positive holistic model. In A. B. Bakker (Ed.), Advances in positive organizational psychology, (Vol. 19) (pp. 145-166). Bingley, UK: Emerald.

Zajacova, A., Lynch, S. M., \& Espenshade, J. E. (2005). Self-efficacy. Stress, and academic success in college. Research in Higher Education, 46, 677-706. Doi 0.1007/s11162-004$4139-\mathrm{z}$

Zimmerman, B., Bandura, A., \& Martinez-Pons, M. (1992). Self-motivation for academic attainment: The role of self-efficacy beliefs and personal goal setting. American Educational Research Journal, 29, 663-676. 
Table 1. Means, standard deviations and correlations among variables, Spanish students $(N=$ 389) and Portuguese students $(N=243)$

\begin{tabular}{|c|c|c|c|c|c|c|c|c|c|}
\hline & \multicolumn{2}{|c|}{ Spain } & & \multicolumn{2}{|c|}{ Portugal } & \multirow[b]{2}{*}{ Min-Max } & \multirow[b]{2}{*}{1} & \multirow[b]{2}{*}{2} & \multirow[b]{2}{*}{3} \\
\hline & $\mathrm{M}$ & SD & Min-Max & $\mathrm{M}$ & SD & & & & \\
\hline 1. PsyCap. & 4.15 & .80 & $1.33-6$ & 4.09 & .93 & $0-5.37$ & - & $.55 * *$ & $.29 * *$ \\
\hline 2. Academic Engagement & 4.01 & .86 & $1-6$ & 3.47 & .95 & $0-6$ & $.62 * *$ & - & $.16^{* *}$ \\
\hline 3. Academic Performance & 7.21 & .71 & $5.5-9.4$ & 7.47 & .64 & $5.5-9.4$ & $.16^{* *}$ & $.14 *$ & - \\
\hline
\end{tabular}

Note. Right of the diagonal shows Spanish students' results. Left of the diagonal shows Portuguese students' results.

$* p<.05, * * p<.01$. 
Table 2. Goodness-of-fit indices for the SEM models

\begin{tabular}{|c|c|c|c|c|c|c|c|c|}
\hline Model & $\chi^{2}$ & $d f$ & $\mathrm{p}$ & SRMR & $\mathrm{CFI}$ & IFI & RMSEA & AIC \\
\hline \multicolumn{9}{|l|}{ Spanish Sample } \\
\hline M1 (Engagement=>Performance) & 629.43 & 201 & .01 & .18 & .87 & .87 & .07 & 733.43 \\
\hline M2 (PsyCap=>Performance) & 608.55 & 201 & .01 & .18 & .87 & .87 & .07 & 712.55 \\
\hline M3 (PsyCap as full mediator) & 460.22 & 200 & .01 & .06 & .92 & .92 & .06 & 566.22 \\
\hline M4 (PsyCap as partial mediator) & 459.79 & 199 & .01 & .06 & .92 & .92 & .06 & 567.79 \\
\hline \multicolumn{9}{|l|}{ M5 (engagement as full } \\
\hline mediator) & 478.27 & 200 & .01 & .06 & .91 & .91 & .06 & 584.27 \\
\hline \multicolumn{9}{|l|}{ M6 (engagement as partial } \\
\hline mediator) & 459.79 & 199 & .01 & .06 & .92 & .92 & .06 & 567.79 \\
\hline \multicolumn{9}{|l|}{ Portuguese Sample } \\
\hline M1 (Engagement=>Performance) & 639.95 & 201 & .01 & .23 & .84 & .84 & .10 & 743.95 \\
\hline M2 (PsyCap=>Performance) & 635.00 & 201 & .01 & .22 & .84 & .84 & .09 & 739.01 \\
\hline M3 (PsyCap as full mediator) & 488.32 & 200 & .01 & .07 & .90 & .90 & .08 & 594.32 \\
\hline M4 (PsyCap as partial mediator) & 487.23 & 199 & .01 & .07 & .90 & .90 & .08 & 596.17 \\
\hline \multicolumn{9}{|l|}{ M5 (engagement as full } \\
\hline mediator) & 492.23 & 200 & .01 & .07 & .89 & .89 & .08 & 598.23 \\
\hline \multicolumn{9}{|l|}{ M6 (engagement as a partial } \\
\hline mediator) & 488.25 & 199 & .01 & .07 & .89 & .89 & .08 & 596.25 \\
\hline
\end{tabular}


Figure1. Research model.

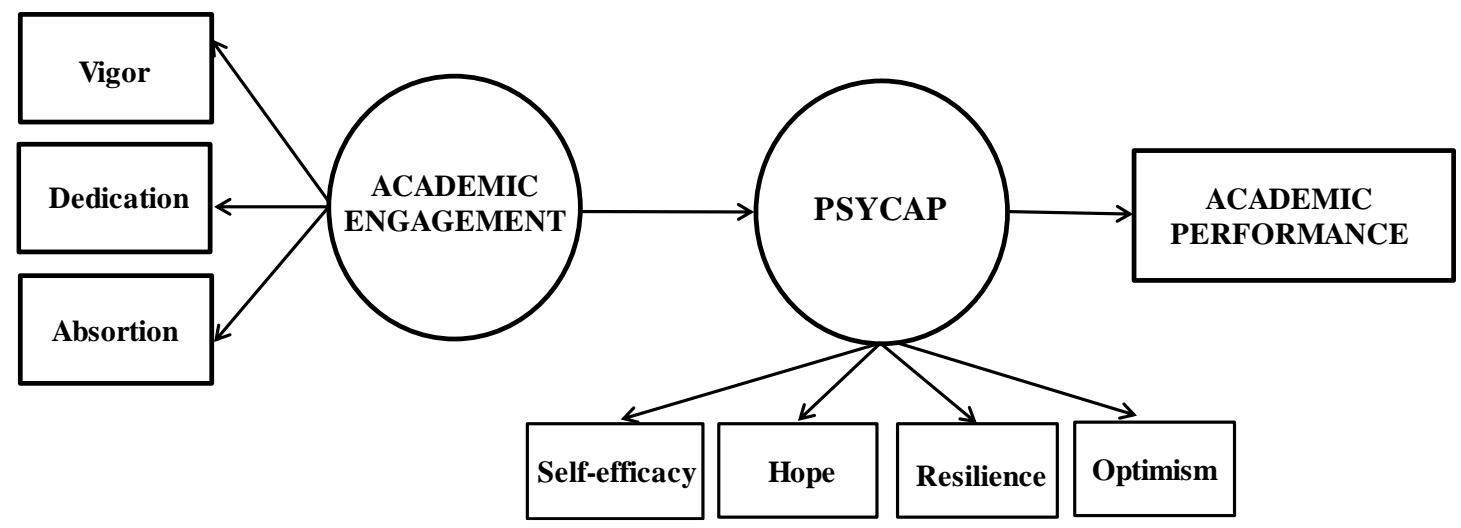


Figure 2. Estimates for Alternative Models.

(a) Model 3 (EngagementPsyCap-Performance - Full Mediation)

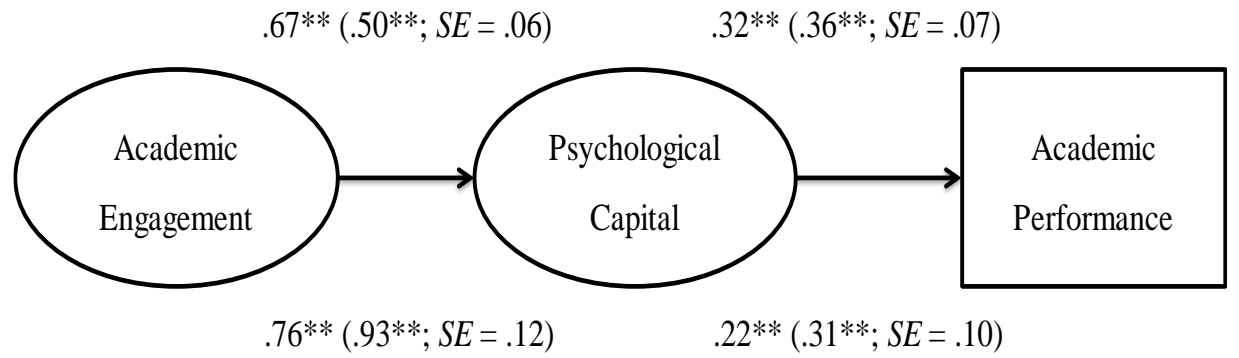

(b) Model 4 (Engagement-PsyCap-Performance - Partial Mediation)

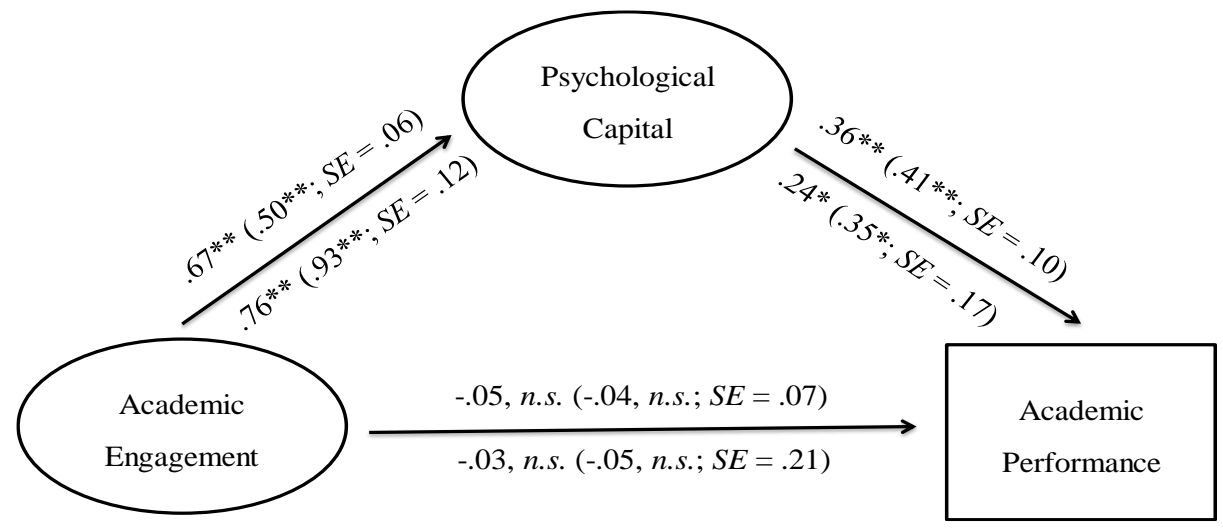

(c) Model 5 (PsyCap-Engagement-Performance - Full Mediation)

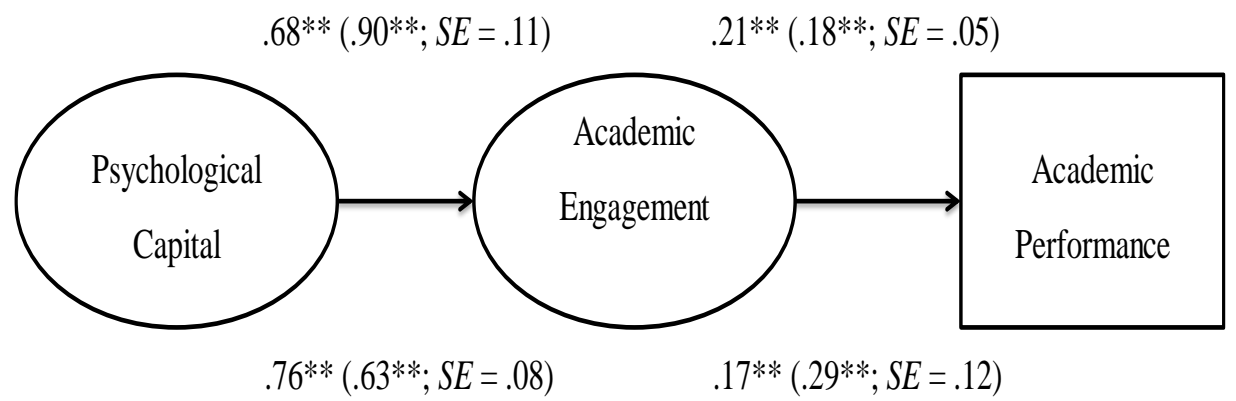

(d) Model 6 (PsyCap-Engagement-Performance - Partial Mediation) 


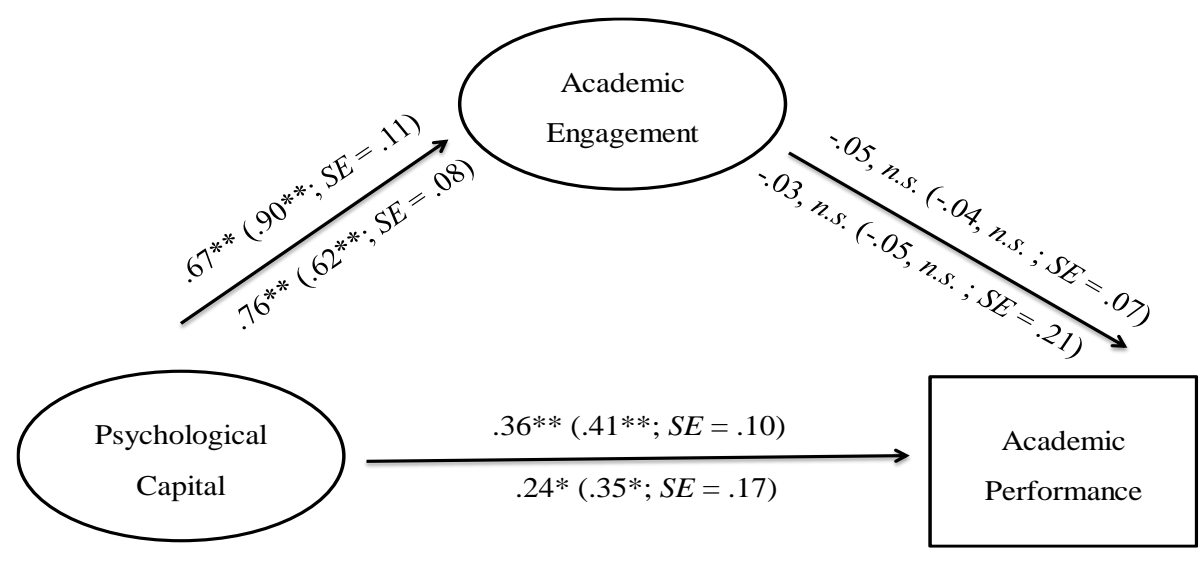

Note: Values above the arrow correspond to results of Spanish Sample, while values below the arrow correspond to results of Portuguese Sample. Values within brackets correspond to unstandardized estimates. ${ }^{* *} p<.01 ;{ }^{*} p<.05$. 